\title{
Work Stress, Perception of Job Safety, and Job Satisfaction of Rope Access Technicians and the Relationship among Them
}

\author{
Iple Erişim Teknisyenlerinin İş Stresi, İş Güvenliği Algıları, İş Tatminleri ve \\ Aralarındaki İlişki Üzerine bir Çalışma
}

\section{Güney ÇETINKAYA* Dicle ARAS ${ }^{* *}$}

\begin{abstract}
Work stress, while affecting employee productivity and job satisfaction, is an important factor that causes serious injuries and even death at work. For this reason, to determine and to propose solutions for those factors affecting job stress is essential for dangerous jobs such as rope access technicians. The main purpose of this study was to examine: job stress, job satisfaction and the perception of job safety of rope access technicians and to show if there are any relations between these factors. The participants in this study were 69 people $(\mathrm{X}$ age $=31.27 \pm 5.33$ ) who volunteered for the study. The data was obtained by means of a form including: the Job Stress Scale developed by Cohen and Williamson (1988) and adapted by Baltaş (1998), the "Job Safety Questionnaire" developed by Hayes et al. (1998) and adapted by Yiğit, Akpınar ve Taş (2016), and the "Minnesota Job Satisfaction Scale" developed by Weiss et al. (1967) and adapted by Baycan (1985). Additionally, a "personal information form" was used in order to collect data concerning demographic information. As a result of this study, it was found that for rope access technicians, job satisfaction was high, the levels of job stress was suitable for health and productivity, and the perceptions of job safety were moderate. Further, it was found that there are positive and meaningful relations between work stress and perceptions of job safety, and negative and meaningful relations between work stress and job satisfaction. The results of regression analysis however, show the perception of job safety and job satisfaction are statistically meaningful precursors of work stress.
\end{abstract}

Keywords: Work Stress, Job Satisfaction, Job Safety, Rope Access Technicians

Öz: İş stresi, çalışanların üretkenliğini ve iş doyumunu etkilemekle birlikte, ciddi yaralanmalara ve hatta ölümlere neden olan önemli bir faktördür. Bu nedenle, iş stresini etkileyen faktörleri belirlemek, iple erişim teknisyenliği gibi risk içeren işler için bir gerekliliktir. Yapılan bu çalışmanın temel amacı, iple erişim teknisyenlerinin iş stresi, iş doyumu ve iş güvenliği algılarını incelemek ve aralarındaki ilişkiyi ortaya koymaktır. Çalışmaya, 69 aktif çalışan iple erişim teknisyeni (X yaş= $31.27 \pm 5.33$ ) gönüllü olarak katılmıştır. Çalışmada veri toplamak amacıyla, Cohen ve Williamson (1988) tarafindan geliştirilen ve Baltaş (1998) tarafindan Türkçe'ye uyarlanan "İş Stresi Envanteri"; Hayes ve ark. (1998) tarafindan geliştirilen ve Yiğit, Akpınar ve Taş (2016) tarafından Türkçe'ye uyarlanan “İş Güvenliği Envanteri” ve Weiss ve ark. (1967) tarafından geliştirilen ve Baycan (1985) tarafından Türkçe'ye uyarlanan "Minnesota İş Tatmini Envanteri" kullanılmıştır. Ayrıca, katılımcıların demografik bilgilerine yönelik verilerin toplanması için araştırmacılar tarafından "kişisel bilgi formu" oluşturulmuştur. Çalışmanın sonucu olarak, iple erişsim teknisyenlerinin iş doyum düzeylerinin yüksek, iş streslerinin çalışanların sağlını ve üretkenliğini etkilemeyecek düzeyde ve iş güvenliği algılarının da orta düzeyde olduğu bulgulanmıştır. Ayrıca, iş stresiyle iş güvenliği algıları arasında pozitif yönlü ve anlamlı ilişki bulunduğu; iş stresiyle iş tatmini arasında negatif yönlü ve anlamlı ilişki bulunduğu tespit edilmiştir. Bununla birlikte, regresyon analizi sonuçları, algılanan iş güvenliğinin ve iş tatmininin iş stresinin istatistiksel olarak anlamlı öncüleri olduğuna işaret etmektedir.

Anahtar sözcükler: İş Stresi, İş Tatmini, İş Güvenliği, İple Erişim Teknisyenleri

\footnotetext{
*Yrd. Doç. Dr., Akdeniz Üniversitesi, Spor Bilimleri Fakültesi, Antalya. gcetinkaya @ akdeniz.edu.tr

** Yrd. Doç. Dr. Ankara Üniversitesi, Spor Bilimleri Fakültesi, Ankara. daras@ankara.edu.tr
} 


\section{Introduction}

Work stress is a psychological condition that deviates an individual from his normal functions and changes his psychological and/or physical behaviors (Iş1khan 2002). Work stress results from factors such as: excessive workload, excessive demand, relations with colleagues, person and environment compliance, environmental conditions, injustice at work, wages, work and house conflict; can cause a variety of consequences from work-related accidents to health problems (Ironson 1992). Moreover, the potential dangerousness in terms of health and safety of the work environment can create a source of stress (Cooper and Davidson 1987). For instance, even the possibility of falls, injuries, poisoning, exposure to radiation, and death are likely to put workers under a degree of stress and anxiety (Cam 2004).

According to the traditional approach, the reasons for accidents in workplaces are classified as (1) engineering-based, originating from insecure situations in the workplace, and (2) employee- based originating from insecure behaviours in the workplace (Heinrich 1931, as cited in Murphy et al. 1986). Nevertheless, studies indicate that $80 \%$ of industrial accidents happen to humans, $18 \%$ due to physical and mechanical environmental conditions, and $2 \%$ are from unexpected events (Camkurt, 2007). Thus, it is possible to say that a large part of work accidents are employee-based (www.safetypartnersltd.com). The risk and stress perceived by employees are related to objective risks, such as having an accident (Rundmo 1995; Rundmo 1996), and these factors increase the number of work accidents (Murphy et al. 1986). Murphy et al. (1986) described the relationship between stress and accidents by means a model. In accord with the model, stress causes acute reactions involving physiological, psychological, and behavioral problems in a short period. These reactions dramatically decrease the cognitive and physical performance of employees. And this decrease in cognitive and physical performance increases the possibility of unsafe behavior. Although many unsafe behaviors do not result in an accident, these behaviors can increase the risk of accident or induce an accident. Work accidents have many consequences such as to a threat to the profitability of business, to decrease the motivation of the employees, to damage and impair the equipment, and more importantly to cause higher insurance expenditure (Huber 1987; Jones \& Wuebker 1993). Apart from this, the economic costs of macro-level job accidents and occupational diseases reach $5 \%$ of the world's national income (ILO 2009, 2). Due to this, occupational health and safety managements systems have been established and implemented in order to eliminate the risks by conducting current situation analyzes in the workplace. Some of the organizations which prepare the standards, laws, and documentations to the world regarding occupational health and safety are:

- American Petroleum Institute (API)

- National Fire Protection Association (NFPA)

- American Society of Mechanical Engineers (ASME)

- Standards New Zealand (SNZ)

- British Standards Institute (BSI)

- Occupational Safety and Health Administration (OHSA)

- Occupational Safety and Health Service

- NZ Chemical Industry Council

- Standards Australia

- International Organization for Standardization (ISO)

Some of the standards implemented are; QS 9000, BS 8800 (Guide To Occupational Health and Safety Management Systems), ILO (International Labor Organization), Occupational Health and Safety Management System Guide 2001, ISA 2000, NPR 5001, OSHA AS/NSZ 4360, 
OSHA AS/NSZ 4804, OHSAS (Occupational Health and Safety Assessment Series) 18001, OHSAS 18002.

Another concept related to job stress is job satisfaction (McGonagle \& Kath 2010). Locke (1976) describes this concept as "a pleasurable or positive emotional state resulting from the appraisal of one's job or job experiences and as a function of the perceived relationship between what one wants from one's job and what one perceives it as offering". High level of job stress is associated with low level of job satisfaction (Fairbrother \& Warn 2003; Hoboubi et al. 2016). Similarly, from the studies conducted, it has been stated that increased job satisfaction causes a decrease in job stress, and there is a negative relationship between job stress and satisfaction (Draper et al. 2004; Yılmaz \& Murat 2008; Erşan et al. 2013). Further, occupational injuries and industrial accidents are likely to be due to the organizational climate and job satisfaction (Gyekye 2005). For this reason, a high level of job satisfaction is thought to contribute to the reduction of occupational injuries and accidents.

A Rope Access Technician (RAT) is a member of a profession that involves reaching out to places, which are usually high and hard to reach, by using a variety of technical equipment and rope techniques and then working in these places. This profession includes the risk of fallrelated injury and/or death due to the environment in which this work takes place. This risk is a major source of stress for the employees. It is a fact that workers in dangerous jobs are more at risk of accidents and fatal accidents than for other professions. Therefore, to determine the factors affecting job stress is essential for high risk jobs such as rope access technicians. The main purpose of this study was to examine the job stress, job satisfaction and the perception of job safety of rope access technicians and to show if there is any relationship between these factors.

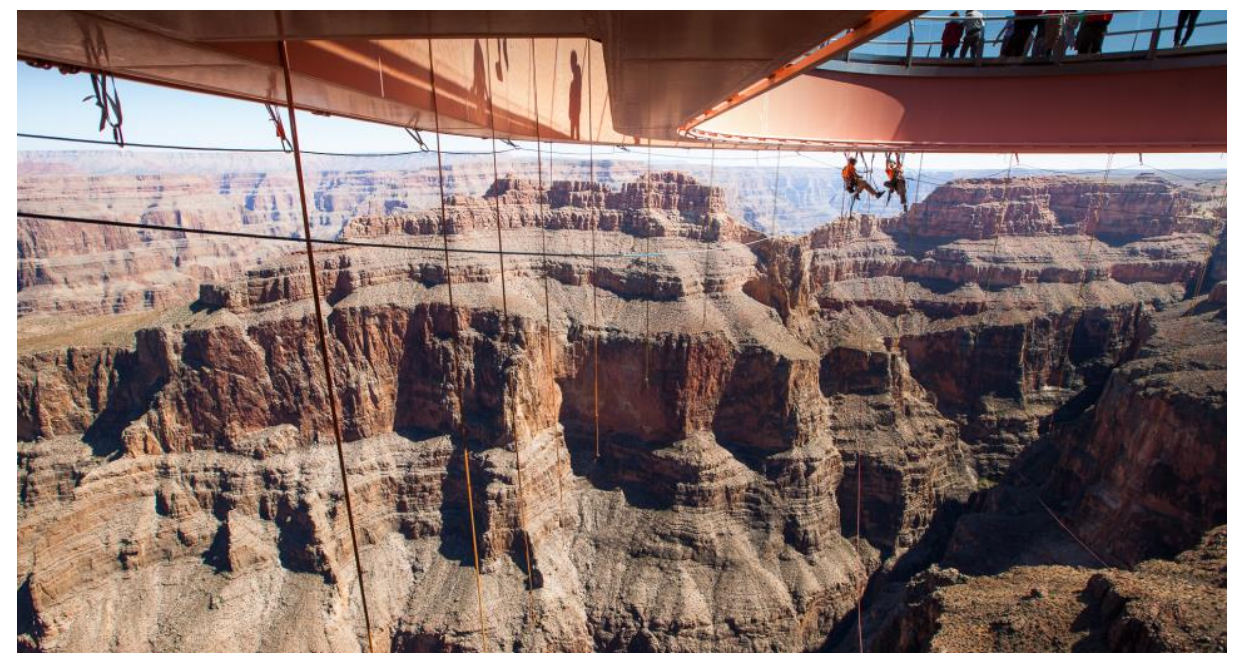

Fig. 1. Rope Access Technicians (www.sprat.org)

\section{Methodology}

\section{Selection and Description of Participants}

The data collection was conducted between January 2016 and October 2016 and administered by e-mail in Turkey. Snowball sampling was used to identify the participants. Snowball sampling is a non-probability sampling technique and used for some populations which are hard to reach (Gabor 2007), such as rope access technicians, who are engaged in a specific activity.

The participants -69 rope access technicians $(\mathrm{X}$ age $=31.27 \pm 5.33)$ - had the following 
characteristics: $97.1 \%$ were male and $2.9 \%$ were female. $66.7 \%$ were single and $33.3 \%$ were married. In terms of educational levels, $66.7 \%$ of the respondents reported having a university education, $21.7 \%$ reported having high school education, $7.2 \%$ reported having postgraduate education and $4.3 \%$ reported secondary school education. Regarding experience of RAT, 34.8 $\%$ of the respondents had worked between 1 and 3 years, $26.1 \%$ between 4 and 6 years, $23.2 \%$ between 7 and 9 years and $15.9 \%$ over 10 years.

\section{Measurements}

Perceived Job Stress Questionnaire: The questionnaire was developed by Cohen and Williamson and the Turkish validity and reliability were made by Baltaş (1998), and the Cronbach alpha value was found to be 0.84 . The questionnaire is a five-point Likert-type consisting of 15 questions. To evaluate the questionnaire the total score obtained is divided by 15 , and thus, the individual's scale score is derived $(\mathrm{A}=1.0-1.3 ; \mathrm{B}=1.4-1.9 ; \mathrm{C}=2.0-2.5 ; \mathrm{D}=2.6$ 3.1; $\mathrm{E}=3.2-3.4 ; \mathrm{F}=3.5-4.0$ ). While $\mathrm{A}, \mathrm{B}, \mathrm{E}$, and $\mathrm{F}$ evaluate the stress level which can affect the efficiency and threat to health, $\mathrm{C}$ and $\mathrm{D}$ evaluated the stress levels that increase success by creating a stimulus effect.

Job Safety Questionnaire: Workers' perceptions of safety were measured with the first dimension of workplace safety scale (WSS) developed by Hayes et al. (1998), with Turkish validity and reliability made by Yiğit, Akpınar ve Taş (2016), and the Cronbach alpha value was found to be 0.91 . This instrument assesses the employees' perceptions of work safety, and measures five distinct constructs each with 10 items: (a) work safety (sample item: "Safety programs are effective"; $\alpha=.96$ ), (b) coworker's safety (sample item: "Pay attention to safety rules"; $\alpha=.80$ ), (c) supervisor safety (sample item: "Enforces safety rules"; $\alpha=.97$ ), (d) management's commitment to safety (sample item: "Responds to safety concern"; $\alpha=.94$ ), (e) satisfaction with safety program (sample item: "Effective in reducing injuries"; $\alpha=.86$ ). The total coefficient $\alpha$ score was .89. Participants responded on a 5-point scale ranging from 1-not at all to 5- very much.

Minnesota Job Satisfaction Questionnaire: This questionnaire was developed in 1967 by Weiss et al. in order to determine the level of job satisfaction, with the Turkish validity and reliability made by Baycan (1985), and the Cronbach alpha value was found to be 0.77 . The questionnaire is a 5-point Likert-type consisting of 20 questions, and can determine the "intrinsic" (12 items) and "extrinsic" (8 items) job satisfaction factors. The neutral saturation score of the questionnaire is 3 . If the score obtained from the questionnaire is smaller than 3 , the job satisfaction is evaluated as low, and if it is larger than 3, the job satisfaction is evaluated as high (Çam et al. 2005).

\section{Data Analyses}

The data derived from the questionnaires were analyzed using the SPSS package program (version 18.0). The level of significance was set to $\mathrm{p}<.05$ and $\mathrm{p}<.01$. Data was analyzed by means of the correlation and regression analysis methods.

\section{Results}

The means, standard deviations and inter-correlations for all measurements used in the present study are reported in Table 1. It was found that for rope access technicians, the job satisfaction level was high, the level of job stress was suitable for health and productivity, and perceptions of job safety was moderate. Furthermore, it was found that there are positive and meaningful relations between job stress and perceptions of job safety, and negative and meaningful relations 
between job stress and job satisfactions.

Table 1. Means, Standard Deviation, Inter-Correlations (Pearson's r) and Cronbach's Alphas in RAT

\begin{tabular}{|l|l|c|c|c|c|c|}
\hline & Variables & Mean & SD & 1 & 2 & 3 \\
\hline 1 & Job stress & 2.54 & .59 & - & $.33^{* *}$ & $-.43^{* *}$ \\
\hline 2 & Work safety & 27.29 & 5.87 & $.33 * *$ & - & -.11 \\
\hline 3 & Job satisfaction & 3.74 & .65 & $-.43 * *$ & -.11 & - \\
\hline$* \mathrm{p}<0.01$. & & & & & \\
\end{tabular}

In the second problem addressed by this study, the power to predict the job stress of the RAT's, their job satisfaction and perceived job safety was investigated. In order to find a response to this question, multiple regression analyses related to predicting the level of the job stress and perceived job safety were done, and its results are presented in Table 2.

Table 2. Regression Model Indicating Factors With Influence on RAT Job Stress

\begin{tabular}{|l|c|c|c|c|}
\hline Variables & $\beta$ & Std. Error & Standardized $\beta$ & $\mathrm{t}$ \\
\hline Constant & 3.128 & .494 & - & 6.332 \\
\hline Job satisfaction & -.367 & .097 & -.401 & $-3.787 * *$ \\
\hline Work safety & .029 & .011 & .285 & $2.691 *$ \\
\hline \multicolumn{2}{|c|}{$\mathrm{R}=0.517$} & $\mathrm{R}^{2}=0.245$ & $\mathrm{~F}=12.029 * *$ & \\
\hline
\end{tabular}

The significance of the analysis of variance in Table 2 at $\mathrm{p}<0.01$ indicates that the variance explained by variables regarding job stress is statistically significant. According to the analyses, job satisfaction and perceived job safety clarifies $25 \%$ of the total variance regarding job stress when they considered together. When the parameters related to the regression model are examined, the standardized regression coefficients $(\beta)$ demonstrate the order of importance of the predictive variables on work stress are job satisfaction $(\beta=-0.401 ;-3.787 ; p<0.01)$ and job safety $(\beta=0.285 ; 2.691 ; \mathrm{p}<0.05)$. According to these results, perceived job safety and job satisfaction are statistically meaningful precursors of job stress.

\section{Discussion and Conclusion}

The present study aimed to investigate the effects of perceived work safety and work satisfaction on job stress by determining the perceived job safety and job satisfaction of Rope Access Technicians. In accord with the results, it could be inferred that the job stress of the Rope Access Technicians is at an acceptable level for health and productivity, their job satisfaction is at the high level, and their perceived job safety level is moderate. In addition there is the positive correlation between job stress and perceived job safety and a negative correlation between job stress and job satisfaction. Furthermore, work satisfaction and perceived work safety are predictors of job stress.

While perceived safety in workplaces improves the productivity of employees (McGonagle and Kath, 2010), reduces their work-related anxiety and stress (Guastello 1992, as cited in Hayes et al. 1998). Apart from this, studies reported that the perceived job safety causes less work accidents (Harrell 1990; Hofmann \& Stetzer 1996). In the present study a positive correlation was found between perceived job safety and job stress unlike that recorded in the literature. Stress is a two-sided phenomenon, and an appropriate stress level can have positive effects (Özkaya, Yakın \& Ekinci 2008). In this respect, an acceptable level of job stress for the 
health and productivity of RAT's can be the cause of this positive correlation.

To date, many studies to determine the relationship between job stress and job satisfaction have been conducted. In the majority of these studies, it was reported that job stress and job satisfaction are interrelated concepts (Ahsan et al. 2009). In these studies, it was concluded that high level of work stress results in a low level of work satisfaction (Landsbergis 1988), and the increase in work satisfaction causes a decrease in work stress (Draper et al. 2004; Y1lmaz \& Murat 2008; Erşan et al. 2013). Therefore, it can be inferred that there is a negative correlation between work stress and work satisfaction. The results of the present study are in line with the literature.

As another substantial result of the current study, it was observed that the perceived job safety and job satisfaction can clarify $25 \%$ of the job stress-related total variance. This result demonstrates that the $75 \%$ of the alteration relating to job stress occurs from other variables excluding perceived job safety and job satisfaction. These results also show that job satisfaction has a higher importance in predicting job stress than perceived work safety. Due to the fact that work stress is an essential factor for work satisfaction (Hoboubi et al. 2016), it is thought that work satisfaction is more predictive of job stress.

Due to its technical nature, rope access technicians have a risky profession and people working as a rope access technician are more likely to have an accident. When it is considered that job stress increases the risk of an accident, it is vital that the stress level of individuals, especially working at risky jobs such as rope access, should be kept to an acceptable level. To conclude, from the findings of the present study, it can be recommended that safety precautions in the work environment should be taken, and some improvements should be made to enhance the job satisfaction level of rope access technicians.

\section{Author' Note}

This paper was presented at The International Journal of Arts \& Sciences Conference at 13 March 2017 as an abstract. 


\section{KAYNAKLAR}

Ahsan N., Abdullah Z., Fie D.Y.G. \& Alam S.S. (2009). "A Study of Job Stress on Job Satisfaction among University Staff in Malaysia: Empirical Study". European Journal of Social Sciences 8/1 (2009) 121- 131.

Baltaş Z., Atakuman Y., Duman Y. (1998). "Standardization of the Perceived Stress Scale: Perceived Stress in Middle Managers". Stress and Anxiety Research Society 19 the International Conference. Boğaziçi University, İstanbul, July 10-12. İstanbul 1998.

Baycan A. (1985). An Analysis of the Several Aspects of Job Satisfaction between Different Occupational Groups. Unpublished Doctoral Thesis. Boğaziçi University, İstanbul 1985.

Cam E. (2004). "Çalışma Yaşamında Stres ve Kamu Kesiminde Kadın Çalışanlar". Uluslararası İnsan Bilimleri Dergisi (2004) 1-10.

Camkurt M. Z. (2007). "İşyeri Çalışma Sistemi ve İşyeri Fiziksel Faktörlerinin İş kazaları Üzerindeki Etkisi." TÜHIS İş Hukuku ve İktisat Dergisi 20/6 (2007) 80-106.

Cohen S. \& Williamson G. M. (1988). "Perceived stress in a probability sample of the United States". Eds. S. Spacapan \& S. Oskamp. The Social Psychology of Health (1988) 31-67. Newbury Park, CA.

Cooper C. L. \& Davidson M. (1987). "Sources of Stress at Work and Their Relation to Stressors in NonWorking Environment”. Eds. R. Kalimo, M. A. El-Batawiet \& C. L.Cooper., Phychosocial Factors at Work (1987) 99-112. Geneva.

Çam O., Akgün E., Babacan G.A., Bilge A. \& Keskin G. Ü. (2005). "Bir Ruh Sağlığı ve Hastalıkları Hastanesinde Çalışan Hekim ve Hemşirelerin Klinik Ortamlarını Değerlendirmeleri İle İş Doyumları Arasındaki İlişkinin İncelenmesi”. Anadolu Psikiyatri Dergisi 6 (2005) 213-220.

Draper J., Halliday D., Jowett S., Norman I., Watson R., Wilson-Barnett J., Normand C. \& O'Brein K. (2004). "NHS Cadet Schemes: Student Experience, Commitment, Job Satisfaction And Job Stress". Nurse Education Today 24 (2004) 219-228.

Erşan E. E., Yıldırım G., Doğan O., Doğan S. (2013). "Sağlık Çalışanlarının Iş Doyumu Ile Algılanan Iş Stresi ve Aralarındaki Ilişkinin Incelenmesi". Anadolu Psikiyatri Dergisi 14 (2013) 115-121.

Fairbrother K \& Warn J. (2003). "Workplace Dimensions, Stress and Job Satisfaction". Journal of Managerial Psychology 18 (2003) 8-21.

Gabor M. R. (2007). "Types of Non-Probabilistic Sampling Used in Marketing Research, Snowball Sampling”. Management \& Marketing (Bucharest) 3 (2007) 80-90.

Guastello S. J. (1992). "Accidents and Stress-Related Health Disorders among Bus Operators: Forecasting with Catastrophe Theory". Eds. J. J. Campbell Quick, L. R. Murphy \& J. J. Hurrell Jr., Stress and Well-Being At Work (1992) 252-269.

Gyekye S. A. (2005). "Workers' Perceptions of Workplace Safety and Job Satisfaction”. International Journal of Occupational Safety and Ergonomics 11/3 (2005) 291-302.

Harrell W. A. (1990). "Perceived Risk of Occupational Injury: Control Over Pace of Work and Blue Collar Work". Perceptions Motor Skills 70 (1990) 1351-1358.

Hayes B., Perander J., Smecko T., Trask J. (1998) "Measuring Perceptions of Workplace Safety: Development and Validation of the Work Safety Scale". Journal of Safety Research 29 (1998) 145-161.

Hoboubi N., Choobineh A., Ghanavati F. K., Keshavarzi S. \& Hosseini A. A. (2016). "The Impact of Job Stress and Job Satisfaction on Workforce Productivity in An Iranian Petrochemical Industry". Safety and Health at Work (In Press) 1-5.

Hofmann D. \& Stetzer A. (1996). "A Cross-Level Investigation of Factors Influencing Unsafe Behaviours and Accidents". Pers Psychol 49 (1996) 307-339.

Huber P. (1987). "Injury Litigation and Liability Insurance Dynamics". Science 283 (1987) 31-36.

ILO (2009). ILO standards on occupational safety and health Promoting a safe and healthy working environment, General Survey concerning the Occupational Safety and Health Convention, 1981 (No. 155), the Occupational Safety and Health Recommendation, 1981 (No. 164), and the Protocol of 2002 to the Occupational Safety and Health Convention, 1981, International Labour Conference, 98th Session, 2009. Report III (Part 1B). Third item on the agenda: Information and reports on the 
application of Conventions and Recommendations. Report of the Committee of Experts on the Application of Conventions and Recommendations (articles 19, 22 and 35 of the Constitution)

Ironson G. (1992). "Work, Job Stress and Health". Ed. S. Zedeck, Work, Families and Organizations, Jossey-Bass (1992) 35. San Francisco.

Işıkhan V. (2002). Çalışma Hayatında Stres Olgusu ve Başa Çıkma Yolları. Ankara 2002.

Jones J. W. \& Wuebker L. J. (1993). "Safety Locus of Control and Enployees' Accidents". Journal of Business and Psychology 7/4 (1993) 449-457.

Landsbergis P. A. (1988). “Occupational Stress Among Health Care Workers: A Test of the JobdemandsControl Model”. Journal of Organizational Behavior 9 (1988) 217-239.

Locke E. (1976). "The Nature and Causes of Job Satisfaction". Ed. M. D. Dunnette, Handbook of Industrial and Organizational Psychology (1976) 1297-1349. Chicago.

McGonagle A. K. \& Kath L. M. (2010). "Work-safety Tension, Perceived Risk, and Worker Injuries: A Meso-Mediational Model”. Journal of Safety Research 41 (2010) 475-479.

Murphy L. R., DuBois D. \& Hurrel J. J. (1986). "Accident Reduction through Stress Management". Journal of Business and Psychology 1 (1986) 5-18.

Özkaya M. O., Yakın V. \& Ekinci T. (2008). "Effect of Stress Levels upon the Job Satisfaction of the Employess: An Emprical Study on Employees of Celal Bayar University". Yönetim ve Ekonomi 15/1 (2008) 163-179.

Rundmo T. (1995). "Perceived Risk, Safety Status, and Job Stress Among Injured and Noninjured Employees on Offshore Petroleum Installations". Journal of Safety Research 26/2 (1995) 87-97.

"Safety Partner Ltd". (2016, December 21). Source: http://www.safetypartnersltd.com/7-most-commoncauses-of-workplace-accidents/\#.WK1V-vmLTIU

"Sprat Offical Web Site”. (2016, December 11). Source:https://sprat.org/

Rundmo T. (1996). “Assosiations between Risk Perception and Safety”. Safety Science 24/3 (1996) 197-209.

Weiss D. J., Dawis R. V., England G. W. \& Lofquist L. H. (1967). Manual for the Minnesota Satisfaction Questionnaire. Minnesota Studies for Vocational Rehabilitation (No. XXII). Minneapolis 1967.

Yılmaz Z. \& Murat M. (2008). "İlköğretim Okulu Yöneticilerinin İş Doyumları ile Örgütsel Stres Kaynakları Arasındaki İlişki”. Fırat Üniversitesi Sosyal Bilimler Dergisi 18 (2008) 204.

Yiğit İ., Akpınar A. T. \& Taş Y. (2016). "İş Güvenliğinin Tükenmişliğe Etkisini Belirlemeye Yönelik Üniversite Hastanesinde Bir Araştırma”. Kastamonu Üniversitesi İktisadi ve İdari Bilimler Fakültesi Dergisi 12 (2016) 53-75. 